\title{
Functional Features of the Spirit of Fire Among the Altai Peoples of Siberia
}

\author{
Nurgun Vyacheslavovich Afanasev*, Vasily Vasilievich Illarionov, Tuyara \\ Vasilievna Illarionova, Olga Ksenofontovna Pavlova, Lyudmila Stepanovna Efimova
}

North-Eastern Federal University named after M.K. Ammosov, Yakutsk, Russia

*Corresponding author. Email: n.v.afanasev@mail.ru

\begin{abstract}
The article discusses the functional features of the symbol of fire. The authors analyze the main functions of the symbol of fire in the traditional culture of the Altai peoples. The spirit of fire among the Altai peoples is presented in a female anthropomorphic image, it is called "От эне" 'Mother Fire'. She acted as a mediator, a mediator between the three worlds according to the traditional picture of the world (Upper, Middle, Lower). She acted as a mediator between the Light deities - Aјас Конга 'Clarity Khan', Ак јайыктан Алтай 'white Yaik Altai', Ульген 'Supreme deity'. According to the ideas of the Altai peoples, the main functional affiliation from эне ('Mother Fire') was the protection of family happiness and the protective function of the entire patrimonial center. In addition to the function of mediator, mediator and patron, the Spirit of Fire also had its purifying function. The authors emphasize that the ancient Altaians constantly performed the rite of consecration by fire and daily treated their patron, the keeper preserved the sacralization of the main function of the Fire Spirit as the patron of man, family and kind.
\end{abstract}

Keywords: fire, Spirit of fire, folklore, Altai peoples, functions

\section{INTRODUCTION}

From the middle of the 19th century, V.V. Radlov, V.I. Verbitsky, N.F. Katanov, G.E. Grumm-Grzhimailo and other researchers began to collect and study materials on oral creativity and ritual folklore of Altai Türks. Until now, the textual materials collected by the above researchers play an important role as primary sources and contain valuable information about the existence of the oral traditions of the Altai peoples. In the 20th century, the study and systematization of the ritual folklore of the Altai Türks is mainly studied from the standpoint of traditional religious beliefs. This can be seen in the works of L.E. Karunovskaya, S.S. Katasha, L.P. Potapova et al. Since the 90s of the twentieth century, the oral folk art of the peoples in question in the works of K.E. Ukachina, D.A. Funk, A.I. Naeva and others are studied at the intersection of folklore, ethnography, art history and cultural studies.

\section{METHODOLOGY AND RESEARCH METHODS}

The authors applied a complex and interdisciplinary approach and structural-typological, lexical and semantic methods of studying the textual materials of the folklore of the Altai people to identify the functional features of the mythological image of the mistress of the fire "OTэне" Ot-ene.

\section{RESULTS AND DISCUSSIONS}

According to the beliefs of the Altai people, every home and public sacrifice was accompanied by sacrificial fire, not a single deity could "taste" the food he sacrificed without the help of fire. To ask spirits about health, the birth of a child, about well-being in the family, about what constitutes life itself, could only be done with the help of fire [1]. A man without fail brought his requests and appeals to higher deities through rituals and poetic wellwishes to the Spirit of fire [2]. The spirit of fire was represented in a female image and was perceived as a living (anthropomorphic) creature. She demanded a special attitude and reverence. However, Ot-ene could sometimes render punitive actions for disrespect for it, neglect, and especially for desecration. Therefore, since ancient times, the Turks of Altai considered Ot-ene ('Mother Fire') the guardian of the clan - a symbol of happiness and the hearth of the family. Each cööк "family" tried to preserve its fire, not to extinguish it and not to transfer it to another family. But in exceptional cases, fire was shared only with relatives or when fire is needed for the sacrifice. According to the ritual, the fire 
Table 1 The good wish to the spirits of the genus

\begin{tabular}{|c|c|}
\hline $\begin{array}{c}\text { Одус башту от-эне, } \\
\text { Ада чапкан ар јалкын, } \\
\text { Эне кӧмгӧн таш очок Бек болзын! }\end{array}$ & $\begin{array}{c}\text { Thirty-head fire mother } \\
\text { Great flame carved by father }\end{array}$ \\
Онон ӧрӧ ӱч очок & Mother rooted stone hearth will be strong! \\
Онон ӧрӧ ӱч сыра, & Above them are three foci, \\
Талкан-кёл обоо болзын, & Above them are three poles, \\
Ӧрӧ турган Ӱлген кудай & Talkan - ash be a stack \\
Баш болзын! & Above (in the sky) the god Ulgen \\
Let it be the head! [4]
\end{tabular}

Altaians believed that when transferring fire from the ail of the "house" along with fire, the Spirit of fire - Ot-ene ('Mother of Fire') can leave. Then this clan can lose happiness, prosperity and bring on the whole clan of illness, since Ot-Ene no longer patronized him. A.V. Anokhin recorded the blessing of a wish addressed to fire, which emphasizes its intermediary function.

Table 2. Good wish to the spirit as a mediator between people and deities

\begin{tabular}{|c|c|}
\hline Ада чаккан от алгын, & Father carved fiery fire, \\
Ана кӧмгӧн таш очок. & His mother is a stone hearth. \\
Ӱч бургалган бӧс тудун, & Gray smoke wriggling three times \\
Ајас Конга томулган. & Clarity - Khan incense, \\
Ӱзӱ чаккан јалыр одым, & My hot, carved fiery fire \\
Јар јанеске эбир кӧр! & Circle around the universe! \\
Ак јайыктан Алтай јаргы сурап турзын! & Let him ask for a solution from the white Yaik Altai! \\
Айдан, кӱннен бир бијени једишсин! & May mercy come from the sun and the month! [5] \\
\hline
\end{tabular}

In this benevolence, a fire in the form of gray smoke reaches Ајас Конга 'Clarity Khan' (one of the epithets of the head of the light deities Ulgen (Ульген)) and asks permission for the mercy of the sun and the month from Ак јайыктан Алтай 'white Yaik Altai'. Based on the materials of mythological texts, Јайыктан is a bright deity, a mediator between Ulgen and people. It is also believed that Јайыктан is part of Ulgen himself, breaking away from the divine body [6]. Then Ot-ene 'Mother of Fire' acts as an intermediary between people and light deities - celestials. L.P. Potapov, exploring the shamanism and hunting of the Altai people, notes that "they especially worship fire on the hunt. What you give to the fire, he will give everything to the mountain owner" [7]. In this one can trace the mediation of fire with the spirits of the middle world. In the funeral rite, the Spirit of fire serves to accompany inventory into the world of the dead - the kingdom of the deity Erlik. The mediating function of fire is not only associated with bright deities and spirits, but also with the Lower World. This reflects the ideas of the ancient Altai people about the three-tiered world: Upper, Middle and Lower [8].

Since ancient times, the Altaians during the ritual actions related to the life cycle have always worshiped the Fire Spirit as the guardian of life and performed ritual actions. During the maternity rite, fire played an important role in the initiation. As noted by N.P. Dyrenkova, some Altai nationalities had a rite of sacrifice to the fire during the wedding. The bridegroom, when the bride remained in his house, performed a religious rite, asking the Spirit of Fire - Ot-Ene blessings and permission for marriage [9]. At wedding ceremonies, at the moment the girl parted with her native hearth, she had to observe the ritual of farewell to her family fire and join the fire of her husband's clan, where she was moving. As D.A. Funk notes about teleuts, "During the wedding, they held a ceremony representing 
the bride of Ot-Ene to enlist her blessing. Such treatment, accompanied by feeding the fire, is pronounced by one of the older men near the stove in the presence of the bride and the accompanying matchmakers and to the matchmakers" [10]. Consequently, during the wedding ceremony, the Altai people asked the Spirit of Fire for blessings and performed the rites of introducing the bride to the bridegroom fire, creating a family union and laying the joint hearth of the newlyweds. After the wedding, the fire was taken from the father's hearth for the newlyweds' homes. But when the newlyweds moved to a new home, the fire of a new family hearth was ignited with the help of a flint. This fire was considered his family fire. Young, lighting a new fire in their ail (home), created their own symbol of happiness and the keeper of the hearth - Ot-ene ('Mother Fire').

The spirit of fire in the funeral rite among the Altai people acted as a mediator between the living and the dead. For example, when a person dies, they feed the fire with their left hand and say: "Eat an early departed soul from here, drink from here!" The last time you eat with us and leave, you don't have to come to us anymore and connect with us, you will leave here forever! "Thus, the ancient Altaians asked the soul of the deceased to no longer remain in the world of the living, since the remaining soul was already considered an evil spirit. Probably, through this petition, people semantically asked the Fire Spirit to protect and protect them from evil spirits. When the last representative of any kind died, the fire was extinguished in the center of his yurt as a sign that life in this family had died out [4]. Apparently, this ritual is confirmed by the fact that Ot-ene was considered an equal member of the family, because without the family she lost her main function - the guardian of the family, clan.

Another functional accessory of the Fire Spirit - Ot-ene 'Mother Fire' was its purifying function. Since ancient times, it was believed that fire does not let evil spirits into the home, scatters evil thoughts of a person, scares the souls of the dead. Therefore, fire cleaned household items and outbuildings. Archyn (juniper) acted as a necessary attribute in such consecration and purification by fire of a sick person.

\section{CONCLUSION}

Thus, the Altai peoples of Siberia honored the fire, respected and worshiped it. Fire in the traditional worldview and in folklore texts has the main function of a mediator, a mediator between a person, spirits and deities. The mediating function of fire was not only associated with the bright deities of the Upper World and the spirits of the Middle World but was also associated with the Lower World. For example, the Spirit of fire acted as a mediator between the living and the dead in a funeral rite. Also, the fire acted as a symbol of family happiness and the keeper of the hearth. This was its main function. The fire also had a purifying and healing function.

\section{REFERENCES}

[1] E.L. Lvov, I.V. Oktyabrskaya, A.M. Sagalaev et al., The traditional worldview of the Turks of Southern Siberia: Man. Society, 1989.

[2] N. Shodoev, Spiritual Wisdom from the Altai Mountains, Moon Books, 2012.

[3] N.V. Afanasev, L.S. Efimova, The elements of fire in mithology of the people of Siberia: general and special, Science and Society 2 (2017) 120-128.

[4] S.S. Katash, Myths, legends of the Altai Mountains, 1978.

[5] A.V. Anokhin, Materials on shamanism among Altai people collected during travels in Altai in 1910 1912 on behalf of the Russian Committee for the study of Central and East Asia, Doe, 2014.

[6] L.P. Hekman, Mythology and folklore of Altai: a training manual, 2000.

[7] D.Y. Doronin, Fire, Flood and War from the East: Cultural Transfer in Altaic Modern Eschatology, Studia Litterarum 3(3) (2018) 278-303. DOI: 10.22455 / 2500-4247-2018-3-3-278-303

[8] N.V. Afanasev, L.S. Efimova, Speech formulas of folklore of the Turkic and Mongolian peoples of Russia, Turkbili 34 (2017) 69-76.

[9] N.R. Oinotkinova, Theonyms yezim and yazhylkhan in the shaman mythology of the altaians, Tomsk journal of Linguistics and Anthropology 2 (2019) 158-168.

[10] D.A. Funk, Worlds of shamans and storytellers: a comprehensive study of Teleut and Shor materials, 2005. 